\title{
Formulation and physicochemical and sensorial evaluation of biscuits supplemented with guava powder
}

\author{
Muhammad Awais Zafar, Tusneem Kausar* and Shahid Mahmood \\ Institute of Food Science and Nutrition, University of Sargodha, Sargodha 40100-Pakistan \\ *Corresponding author's email: tusneem.kausar@uos.edu.pk \\ Citation \\ Muhammad Awais Zafar, Tusneem Kausar and Shahid Mahmood. Formulation and physicochemical and sensorial \\ evaluation of biscuits supplemented with guava powder. Pure and Applied Biology. Vol. 8, Issue 2, pp1588-1591. \\ http://dx.doi.org/10.19045/bspab.2019.80100

\begin{tabular}{llll}
\hline \hline Received: 14/12/2018 & Revised: 18/04/2019 & Accepted: 22/04/2019 & Online First: 26/04/2019 \\
\hline
\end{tabular}

\section{Abstract}

The present study was aimed at assessing the effect of supplementing wheat flour with guava powder on physic-chemical and sensory characteristic of biscuits. Guava fruit was prepared as dehydrated powder and used at different levels $(0,2.5,5,7.5$ and 10\%) of wheat flour substitution for biscuit formulation. The effects of guava powder supplementation on physicochemical and sensory characteristics of biscuits were evaluated. Diameter of guava flour supplemented biscuits increased (from $4.72 \mathrm{~cm}$ to $4.86 \mathrm{~cm}$ ) while spread ratio decreased (from 9.44 to 9.00 ), significantly. Protein (6.54\% to $9.03 \%)$ and fiber $(0.24 \%$ to $1.8 \%$ ) also increased significantly by increasing the concentration of guava flour while moisture, fat and ash remain unchanged and NFE decreased. Sensory evaluation of biscuits showed that supplementation of guava flour improve color, texture, taste, aroma and over all acceptability. The supplementation seems to be suited for wheat flour substitution and it is possible to obtain biscuits of better quality within the standard for biscuits. Keywords: Biscuits; Guava powder; Physicochemical; Sensory evaluation; Supplementation

\section{Introduction}

Fruits are gift of nature which provides a number of essential vitamins and minerals that are deficient in other foods or present in small quantities. Seasonal supply of fruits results in economic loss and spoilage of large quantities of fruits. To avoid the spoilage of large quantities of fruits, they can be processed into various products like syrups, squashes, candy, jelly, jams etc. Another option is to dehydrate these fruits into powder and use in development of value added products which contribute significantly to the therapeutic as well as nutritive value. Development of value added products based on fruit powders have excellent sensory characteristics, reduce the post-harvest losses and contribute in improving the health status of people [1].

Pakistan is one of the largest guava producing countries in the world with two harvesting seasons, winter and summer. To prevent postharvest losses, it is important to market it immediately after harvesting. Other option is to process and preserve in different forms. Drying of the fruit can be an alternate to increase shelf-life by converting perishable commodity into a stable product by lowering water activity. It also improves the quality by preventing microbial growth and biochemical reactions. Drying also facilitate handling, storage and transportation of fruits which is important in the globalized world [2].
Biscuits are common bakery item due to their nutritional quality, ease of use, availability of different types and also affordability by people. Nutritional diversification of biscuits is common and easy by adding different ingredients. Such ingredients improve nutritional value of biscuits making them healthier for customers and also modify/enhance the sensory characteristics of the product [3-5]. Fruit residues are important source of nutrients which fulfill the consumer demand for healthier food [6].

It was stated that the incorporation of wheat flour with unconventional powders improves the nutritional quality and palatability of cookies making them more accepted by consumers [7]. So, bakery products especially biscuits and cookies can be manufactured using different flours due to economic and nutritional reasons [8-10].

This study was aimed at processing guava into powder, develop a biscuit formulation from supplementing guava powder with wheat flour with good acceptability and evaluate its effect on the physicochemical and sensory characteristics of biscuits produced.

\section{Materials and methods}

Preparation of guava powder

Guava fruit, the surahi variety was purchased from local market, Sargodha, Pakistan. After removing the unwanted residues, fruits were cut into slices $(1.0 \mathrm{~cm}$ thickness $)$ and dried at 
$60-65^{\circ} \mathrm{C}$. During drying, slices were turned occasionally to enhance even drying. The process of drying was continued until the moisture content remains $4.0 \%$. Dried slices were ground and into sieved into particle size of $100 \mu \mathrm{m}$. The guava powder was packed in low density polyethylene bags and stored in airtight container for further analysis and use.

\section{Preparation of biscuits}

The biscuits were made according to the method described by [11] with some modification. Guava powder was replaced with wheat flour at a concentration of $0,2.5$, $5,7.5$ and $10 \%$. Shortening and sugar were mixed until a light and fluffy cream formed. Eggs were added while mixing. Then wheat flour, guava powder, baking soda and salt were slowly introduced into the mixture. The batter was shaped into biscuits and then baked in oven at temperature of $150^{\circ} \mathrm{C}$ for 15 $20 \mathrm{~min}$. After cooling, biscuits were stored in airtight container for further analysis. Different formulations used for the preparation of biscuits are shown in (Table 1).

\section{Physical analysis of biscuits}

Biscuits were evaluated for diameter $(\mathrm{cm})$, thickness $(\mathrm{cm})$ and spread ratio (diameter/thickness) according the standard method [12]. Diameter and thickness were determined using vernier caliper and weight was measured using an electronic weighing balance. Spread ratio was calculated as diameter/thickness.

\section{Chemical composition of biscuits}

Moisture, protein, fat, ash, fiber and NFE contents were determined according to the official methods of the AOAC [13].

\section{Sensory evaluation of biscuits}

Sensory evaluation was conducted using a semi-trained panel of twenty judges. Coded samples of biscuits were presented to each of the judges and they were asked to assess the biscuits for color, texture, taste, aroma and overall acceptability according to the described procedure [14].

\section{Statistical analysis}

All analytical determinations were conducted in triplicates. The means were calculated and data obtained were subjected to analysis of variance (ANOVA) and the significance was compared using LSD [15].

\section{Results and discussion \\ Physical characteristics of biscuits}

Biscuits prepared from wheat flour substituted with guava powder at $0,2.5,5,7.5$ and $10 \%$ were evaluated for various physical characteristics. The mean values are presented in (Table 2). The data recorded a gradual increase in width of guava powder substituted biscuits from $4.72 \mathrm{~cm}$ to $4.86 \mathrm{~cm}$ without larger changes in thickness. The values for spread ratio decreases with addition of guava powder in biscuits significantly. The obtained results are in complete agreement with those of Chinma and Gernah [16]. Several researches showed the reduction of spread ratio of cookies and biscuits when wheat flour is supplemented with non-wheat flour $[7,17,18]$.

\section{Chemical composition of biscuits}

In (Figure 1) showed the chemical composition of biscuits prepared without and with different concentrations of guava powder. There were no significant difference in moisture, fat and ash content of all the treatments. Uchoa et al., [1] reported $11.47 \%$ of proteins and $24.29 \%$ fibre in guava fruit powder. Hence, addition of guava powder increased the protein content from 6.54 to $9.03 \%$ and fibre from 0.24 to $1.8 \%$ in biscuits

\section{Sensory characteristics}

The sensory characteristics of the studied wheat biscuits as influenced by the incorporation of guava powder are outlined in (Table 3). There was significant difference in relation to the sensorial attributes in biscuits when the level of the guava powder supplementation increased. The biscuits with $5 \%$ had the highest hedonic scale rating and with $10 \%$ showed the lowest scores. In a study [1] sensory analysis in cookies with cashew apple and guava powder demonstrated that replacement of wheat flour upto $20 \%$ guava flour improve all sensorial parameters while $20 \%$ cashew apple flour showed lower scores. In another study [19] enrichment of cookies with passion fruit powder improves the nutritional quality without affecting sensory quality. The results of different research showed that higher the level of substitution the lower the overall acceptability [20-22].

Table 1. Biscuit formulation with different percentages of guava powder

\begin{tabular}{|c|c|c|c|c|c|}
\hline \multirow{2}{*}{ Ingredients } & \multicolumn{4}{|c|}{ Level of substitutions } & \multirow[b]{2}{*}{$\mathbf{T}_{4}$} \\
\hline & $\mathbf{T}_{\mathbf{0}}$ & $\mathbf{T}_{1}$ & $\mathbf{T}_{2}$ & $\mathbf{T}_{\mathbf{3}}$ & \\
\hline Wheat flour $(\mathrm{g})$ & 100 & 97.5 & 95 & 92.5 & 90 \\
\hline Guava powder (g) & 0 & 2.5 & 5 & 7.5 & 10 \\
\hline Shortening (g) & 60 & 60 & 60 & 60 & 60 \\
\hline Sugar (g) & 40 & 40 & 40 & 40 & 40 \\
\hline Salt (g) & 0.8 & 0.8 & 0.8 & 0.8 & 0.8 \\
\hline Leavening agent $(\mathrm{g})$ & 1.6 & 1.6 & 1.6 & 1.6 & 1.6 \\
\hline Eggs (medium) & 2 & 2 & 2 & 2 & 2 \\
\hline
\end{tabular}


Table 2. Physical evaluation of wheat flour biscuits supplemented with guava powder

\begin{tabular}{|c|c|c|c|}
\hline Treatments & Diameter $(\mathbf{c m})$ & Thickness $(\mathbf{c m})$ & Spread ratio (diameter/thickness) \\
\hline $\mathrm{T}_{0}$ & $4.72^{\mathrm{c}}$ & $0.50^{\mathrm{a}}$ & $9.44^{\mathrm{a}}$ \\
\hline $\mathrm{T}_{1}$ & $4.77^{\mathrm{bc}}$ & $0.51^{\mathrm{a}}$ & $9.35^{\mathrm{a}}$ \\
\hline $\mathrm{T}_{2}$ & $4.82^{\mathrm{ab}}$ & $0.54^{\mathrm{a}}$ & $8.93^{\mathrm{b}}$ \\
\hline $\mathrm{T}_{3}$ & $4.87^{\mathrm{a}}$ & $0.53^{\mathrm{a}}$ & $9.18^{\mathrm{b}}$ \\
\hline $\mathrm{T}_{4}$ & $4.86^{\mathrm{a}}$ & $0.54^{\mathrm{a}}$ & $9.00^{\mathrm{b}}$ \\
\hline
\end{tabular}

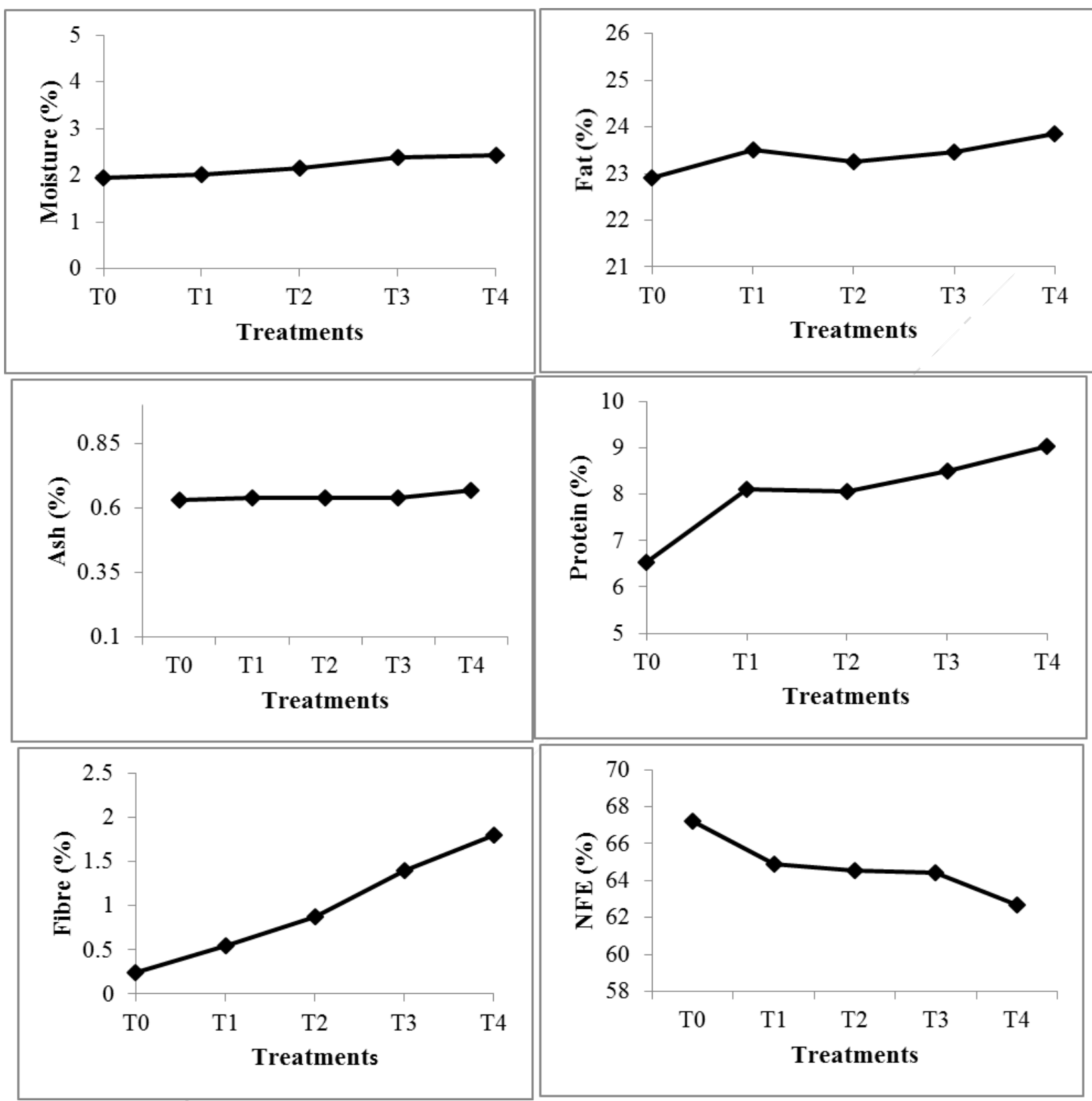

Figure 1. Chemical composition of wheat flour biscuits supplemented with guava powder

Table 3. Mean sensory score of biscuit made from wheat flour supplemented with guava powder

\begin{tabular}{|c|c|c|c|c|c|}
\hline Treatments & Color & Texture & Taste & Aroma & Overall acceptability \\
\hline $\mathrm{T}_{0}$ & $8.9^{\mathrm{a}}$ & $8.4^{\mathrm{a}}$ & $8.5^{\mathrm{a}}$ & $8.6^{\mathrm{a}}$ & $8.5^{\mathrm{a}}$ \\
\hline $\mathrm{T}_{1}$ & $7.6^{\mathrm{b}}$ & $6.9^{\mathrm{b}}$ & $8.6^{\mathrm{a}}$ & $6.9^{\mathrm{b}}$ & $8.0^{\mathrm{a}}$ \\
\hline $\mathrm{T}_{2}$ & $8.5^{\mathrm{a}}$ & $7.9^{\mathrm{a}}$ & $8.0^{\mathrm{a}}$ & $8.5^{\mathrm{a}}$ & $8.1^{\mathrm{a}}$ \\
\hline $\mathrm{T}_{3}$ & $5.8^{\mathrm{c}}$ & $5.9^{\mathrm{c}}$ & $8.4^{\mathrm{b}}$ & $5.7^{\mathrm{c}}$ & $5.7^{\mathrm{b}}$ \\
\hline $\mathrm{T}_{4}$ & $6.3^{\mathrm{c}}$ & $6.1^{\mathrm{c}}$ & $7.6^{\mathrm{b}}$ & $6.2^{\mathrm{bc}}$ & \\
\hline
\end{tabular}

\section{Conclusion}

Preparations of biscuits using guava powder in partial replacement of wheat flour improve the nutritional quality by increasing protein and fibre content. With regard to sensory evaluation, biscuits with $5 \%$ guava powder were very well accepted. So, it could be concluded that dehydrated guava powder could be used as a suitable source of protein and dietary fiber in biscuits.

Authors' contributions

Conceived and designed the experiments: $\mathrm{T}$ Kausar \& MA Zafar, Performed the experiments: MA Zafar, Analyzed the data: T Kausar, MA Zafar, Contributed reagents/ 
materials/ analysis tools: T Kausar, MA Zafar \& S Mahmood, Wrote the paper: T Kausar.

\section{References}

1. Uchoa AMA, Correia de Costa JM, Maia GA, Meira TR \& Sousa PHM (2009). Formulation and physicochemical and sensorial evaluation of biscuit type cookies supplemented with fruit powders. Plant Foods Hum Nutr 64: 153-159.

2. Kumar K \& Kumar N (2012). Development of vitamin and dietary fibre enriched carrot pomace and wheat flour based buns. J Pure Appl Sci Tech 2(1): 107-115.

3. Aquino ACMS, Moes RS, Leao KMM, Figueiredo AVD \& Castro AA (2010). Avaliacao fisico-quimica e aceitacao sensorial de biscuitos tipo cookies elaborados com farinha de residuos de acerola. Revista do Instituto Adolfo Lutz 63(3): 379-386.

4. Turkosy S \& Ozakaya B (2011). Pumpkin and carrot pomace powders as a source of dietary fiber and their effects on the mixing properties of wheat flour dough and cookie quality. Food Sci Technol Res 17(6): 545-553.

5. Bertagnolli SMM, Silveira MLR, Fogaca AO, Umann L \& Penna NG (2014). Bioactive compounds and acceptance of cookies made with guava peel flour. Food Sci Technol Campinas 34(2): $303-$ 308.

6. Inyang UE, Daniel EA \& Bello FA (2018). Production and quality evaluation of functional biscuits from whole wheat flour supplemented with Acha (Forio) and kidney bean flour. Asian J Agri Food Sci 6(6): 193-202.

7. Santucci MCC, Alvim ID, Faria EV \& Sgarbieri VC (2003). Efeito do engriguecimento de biscoitos tipo agua e sal com extato de levendura (Saccharomyces sp.). Ciencia $e$ Tecnologia de Alimentos 23(4): 441-446.

8. Nassar AG, Abdel-Hamied AA \& ElNaggar EA (2008). Effect of citrus byproducts flour incorporation on chemical, rheological and organoleptic characteristics of biscuits. World J Agri Sci 4(5): 612-616.

9. Assis LM, Zavarize ER, Raunz AL, Dias ARG, Gutkoski LC \& Elias MC (2009). Propriedades nutricionais, technologicas e sensoriais de biscoitos com substituicao de farinha de trigo por farinha de aveia ou farinha de arroz parboilizado. Alimentos e Nutricao 20(1): 15-24.
10. Kohajdova Z, Karovicova J \& Jurasova $M$ (2012). Influence of carrot pomace powder on the rheological characteristics of wheat flour dough and on wheat rolls quality. Acta Sci Pol Technol Aliment 11(4):381-387.

11. Oyewole OB, Sanni LO \& Ogunjobi MA (1996). Production of biscuits using cassava flour. Nig Food J 14: 24-29.

12. AACC (2000). Approved methods of the American Association of Cereal Chemists. $10^{\text {th }}$ Ed. St. Paul, Mn, USA.

13. AOAC (2000). Official Methods Analysis of AOAC, International published by AOAC. Wilson Boulevard Arlington, Virginia, USA.

14. Meilgaard MC, Civille GV \& Carr BT (2007). Sensory Evaluation Techniques, $4^{\text {th }}$ Ed. CRC Press, New York, NY, USA.

15. Steel RGD, Torrie JH \& Dickey DA (1997). Principles and procedures of statistics. A biometrical approach. Singapore. $3^{\text {rd }}$ Ed. McGraw Hill Book Co. Inc., New York, USA. Pp: 400-428.

16. Chinma CE \& Gernah DI (2007). Physicochemical and sensory properties of cookies produced from cassava/soyabean/mango composite flours. J Food Tech 5(3): 256-260.

17. Bilgicli NS, Ibanoglu S \& Kerken EN (2007). Effect of dietary fiber addition on the selected nutritional properties of cookies. J Food Eng 78:86-89.

18. Ashoush IS \& Gadallah MGE (2011). Utilization of mango peels and seed kernels powders as source of phytochemicals in biscuit. World J Dairy Food Sci 6(1):35-42.

19. Costa JN, Soares DJ, Carneiro AP, Moura SM, Rodrigues CS \& Figueiredo W (2012). Composicao centesimal e avaliacao sensorial de biscoitos tipo cookies acrescido de maracuja em po. Revista Brasileira de Produtos Agroindustriais 14(2):143-147.

20. Gambus H, Mikulec A \& Matusz A (2003). The Canadian muffins and hermit cookies with linseeds. Zywnosc 10(3): 82-92.

21. Hussain S, Anjum FM, Butt MS, Khan MI \& Asghar A (2006). Physical and sensoric attributes of flaxseed flour supplemented cookies. Tarkish J Bio 30(2): 87-92.

22. Idowu OA \& Akinsola AO (2017). Effect of processing techniques on the overall quality attributes of cookies produced from Jackbeans and wheat flour. J Sci Agri 1:365-371. 